ZOOLOGIA 31 (5): 496-502, October, 2014

http://dx.doi.org/10.1590/S1984-46702014000500010

\title{
A new species of Quinquelaophonte (Copepoda: Harpacticoida) from Argentina
}

\author{
Michel Sciberras ${ }^{1,2}$, Verónica Natalia Bulnes ${ }^{1} \&$ Néstor J. Cazzaniga ${ }^{1}$ \\ ' Departamento de Biología, Bioquímica y Farmacia, Universidad Nacional del Sur. San Juan 670, Bahía Blanca 8000, \\ Buenos Aires, Argentina. \\ ${ }_{2}^{2}$ Corresponding autor. Email: sciberras.michele@gmail.com
}

\begin{abstract}
Quinquelaophonte aestuarii sp. nov. (Copepoda, Harpacticoida) from Bahía Blanca estuary is the first record of Quinquelaophonte Wells, Hicks \& Coull, 1982 in Argentina and its southernmost location in the world. The setal formula (P2: exopod 1.2.3-endopod 1.2.0; P3: exopod 1.2.3-endopod 2.2.1; P4: exopod 1.2.3-endopod 1.2.0) of the last segment of P2-P4, in both the exopod and the endopod, distinguishes this species from all known species in Quinquelaophonte, except for Quinquelaophonte varians Bjornberg, 2010. The new species differs from the latter in the setal formula of the antennule, the mouth parts and maxillipeds, the absence of an inner seta on the second exopod segment of P2, the length of the second exopod segment of P4 and in the shape of baseoendopod setae of P5.
\end{abstract}

KEY WORDS. Buenos Aires province; Laophontidae; meiofauna; taxonomy.

The taxonomic knowledge of the marine harpacticoid fauna of Argentina is mostly limited to the southernmost coasts of Patagonia, where Rosa Pallares performed a sustained study of this group, mainly focused on Ría Deseado (47²4'S) (Pallares 1966, 1968a, b, c, 1969a, b, 1970, 1973a, b, 1975a, b), Isla de los Estados (544'ㅇ) (Pallares 1975c, d, 1977, 1979), and Tierra del Fuego $\left(>54^{\circ} 48^{\prime} \mathrm{S}\right.$ ) (Pallares 1982$)$. The only specific record to the north of Ría Deseado is Eutelpe minuta

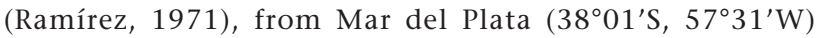
(RAmírez 1971).

Copepods of Laophontidae Scott, 1905 possess a characteristic first prehensile leg with a two-segmented endopod and a distal protruding claw and a small seta (LANG 1948). This family includes Quinquelaophonte Wells, Hicks \& Coull, 1982, with ten known species: Q. quinquespinosa (Sewell, 1924) from Africa, India, USA, Europe and Brazil; Q. bunakenensis Mielke, 1997 and Q. koreana Lee, 2003 from southeastern Asia; Q. wellsi (Hamond, 1973) and Q. prolixasetae Walker-Smith, 2004 from Australia; Q. candelabrum Wells, Hicks \& Coull, 1982 from New Zealand; Q. capillata (Wilson, 1932) and Q. longifurcata (Lang, 1965) from USA; Q. parasigmoides (Bozic, 1969) from Europe; Q. varians Bjornberg, 2010 from Brazil.

The only previous records of this genus in South America were from Brazil: Quinquelaophonte quinquespinosa (Sewell, 1924) (as Heterolaophonte sigmoides Willey, 1930), and Q. varians Bjornberg, 2010.

Quinquelaophonte aestuarii sp. nov. from Bahía Blanca estuary is the first record of Quinquelaophonte Wells, Hicks \&
Coull, 1982 in Argentina and this record represents its southernmost location in the world.

\section{MATERIAL AND METHODS}

The studied area is located in the Bahía Blanca estuary whose hydrological and ecological conditions were described by Piccolo \& Perillo (1990). The collecting locality is the middle fringe of the midlittoral beach at Arroyo Pareja (38 53'S, $\left.62^{\circ} 07^{\prime} \mathrm{W}\right)$, three kilometers far from Punta Alta city, southwestern Buenos Aires province. The midlittoral beaches of the estuary are silt-clayey with average values of $36 \%$ silt, 34\% clay, 25\% sand and 5\% gravel; some sparse stones are present on the sediment surface. The mostly homogeneous landscape alternates with patches of Spartina alterniflora Loisel (V.N. Bulnes, unpubl. data).

Sampling was carried out in October 2011 and February 2013. The sediment was extracted with $3 \mathrm{~cm}$ diameter plastic corers during low tide, within patches dominated by $S$. alterniflora. The samples were fixed in $4 \%$ formalin saturated with Bengal Rose. The specimens were separated by elutriation and filtered with 125-225 $\mu$ m diameter sieves (Higgins \& Thiel 1988). Fixed specimens were photographed and their appendages dissected and mounted on glycerol. All drawings have been prepared using a Bausch \& Lomb optical microscope and oil immersion objective (X1000).

The type series is housed at the Museo Argentino de Ciencias Naturales "Bernardino Rivadavia" (MACN); in Buenos Aires City, Argentina. A DeLTa database (DALlwitz 1993 onwards) of Quinquelaophonte is available for further information. 


\section{TAXONOMY}

\section{Quinquelaophonte aestuarii sp. nov.}

Description of the female (holotype). Length from the point of rostrum to the end of the furcal ramus: $0.609 \mathrm{~mm}$. Using a voucher of 13 female specimens, including the holotype and paratypes, the total length varied from 0.569 to 0.741 $\mathrm{mm}$ (mean $=0.637 \mathrm{~mm}$, standard deviation $=0.028$, median $=$ $0.621 \mathrm{~mm}$ ). Body cylindrical and elongate, with spinules scattered over the dorsal surface (Fig. 1). With a ventral egg sac (Fig. 2). Rostrum rounded with two sensory setules (Fig. 1). Urosome: genital double urosomite dorsally subdivided. Genital field with seminal receptacles and seminal duct (Fig. 3). Urosomites bearing a ventral marginal posterior row of spinules, as the genital urosomite. Anal operculum with two minute setae on each side (Fig. 4). Furcal rami (Figs 4-6) four times longer than wide, bearing marginal posterior rows of spinules on ventral surface. Furcal setae (Fig. 4): two outer lateral short setae (I, II); seta III absent; a long outer terminal seta (IV), a long, strong, $0.208 \mathrm{~mm}$ seta (V); a short inner terminal seta (VI); and a short dorsal seta (VII). Using a voucher of 13 specimens, including the holotype and paratypes, the length of the terminal seta $(\mathrm{V})$ varied between $0.160 \mathrm{~mm}$ and $0.264 \mathrm{~mm}$ (mean = $0.213 \mathrm{~mm}$, standard deviation $=0.007$, median $=0.21 \mathrm{~mm})$. Antennule (Fig. 7): six-segmented. An acrothek (aesthetasc fused basally to two setae) on fourth segment and terminal segment with an aesthetasc fused basally to one seta. Setal formula: 1(1),2(8),3(6),4(acrothek),5(1),6(7+(1+ae)). Antenna (Fig. $8)$ : allobasis with spinules medially located on the inner margin. Exopod reduced to single segment with three short setae. Endopod with spinules medially located on the inner margin, three subdistal spinules, three lateral spines and four terminal setae, three of them geniculate. Mandible (Fig. 9): gnathobase bearing two bicuspidate teeth and two setae on the distal margin. Palp small, with endopod and exopod fused to basis, represented by small pedestal bearing two setae each. Basal armature represented by three setae. Maxillule (Fig. 10): arthrite with two strong terminal spines. Coxa with two setae. Basis bearing three setae. Endopod forming small pedestal with two setae. Exopod one-segmented with two setae. Maxilla (Fig. 11): syncoxa with rows of spinules; with one endite, bearing three distal setae and a lateral element; allobasis drawn into strong claw with rows of spinules and four setae, two on each side. Maxilliped (Fig. 12): prehensile. Basis with two setae and rows of spinules. First endopod segment elongate, without surface spinules. Terminal claw as long as endopod segment. P1 (Fig. 13): basis with rows of spinules and a bipinnate spinulose outer spine. Exopod two-segmented, both segments with rows of outer spinules; first segment shorter than the second, with oblique rows of spinules and one outer spine; second segment with two outer spines, a distal outer spine and two apical geniculate setae. Endopod two-segmented, prehensile; first segment longer than exopod, with inner spinules; second segment with one short seta, one spinule and a claw. P2-P4 (Figs 14-16): basis with rows of spinules and a smooth spine in P2 and a smooth seta in P3 and P4. P2 (Fig. 14): exopod three-segmented; all segments with rows of outer spinules; first segment with oblique rows of spinules and a bipinnate outer spine; second segment with a bipinnate outer spine and one plumose inner seta; third segment with three bipinnate outer spines, two long plumose apical setae and a plumose inner seta. Endopod two-segmented; both segments with long inner setules; second segment with tiny outer setules, two long plumose apical setae and one long plumose inner seta. P3 (Fig. 15): exopod three-segmented; all segments with rows of outer spinules; first segment with oblique rows of spinules and a bipinnate outer spine; second segment with a bipinnate outer spine and one inner seta; third segment with three bipinnate outer spines, two long apical setae and one plumose inner seta. Endopod two-segmented; both segments with long inner setules; first segment unarmed; second segment with one bipinnate outer spine, two long plumose apical setae and two plumose inner setae. P4 (Fig. 16): exopod three-segmented; all segments with rows of outer spinules; first segment with oblique rows of spinules and one bipinnate outer spine; second segment with one bipinnate outer spine and one plumose inner seta; third segment with three bipinnate outer spines, two long plumose apical setae and one plumose inner seta. Endopod two-segmented; both segments with long inner setules; second segment with two long plumose apical setae and one long plumose inner seta. Armature formula as in Table I. P5 (Fig. 17): baseoendopod with rows of setules; baseoendopodal lobe with five setae, plus outer basal seta. Exopod with six setae and several inner setules.

Table I. Setal formula for the P1-P4 swimming legs of Quinquelaophonte aestuarii sp. nov. female.

\begin{tabular}{ccc}
\hline & Exopod & Endopod \\
\hline P1 & $\mathrm{I}-0 ; \mid \mathrm{II}, 2,0$ & $0-0 ; 0,11,0$ \\
P2 & $\mathrm{I}-0 ;|-1 ;| I \mid, 2,1$ & $0-0 ; 0,2,1$ \\
P3 & $\mathrm{I}-0 ;|-1 ;| I \mid, 2,1$ & $0-0 ; \mid, 2,2$ \\
P4 & $\mathrm{I}-0 ;|-1 ;| I \mid, 2,1$ & $0-0 ; 0,2,1$ \\
\hline
\end{tabular}

Description of the male (allotype). Length from the point of rostrum to the end of the furcal ramus: $0.679 \mathrm{~mm}$. Using a voucher of 13 male specimens, including the allotype and other paratypes, the total length varied from $0.574 \mathrm{~mm}$ to $0.771 \mathrm{~mm}$ (mean $=0.684 \mathrm{~mm}$, standard deviation $=0.035$, median $=0.69$ $\mathrm{mm}$ ). Body cylindrical and elongate (Figs 18-19), with spinules scattered over dorsal surface. Rostrum rounded (Fig. 18). Urosome: the last three segments bearing ventral marginal posterior rows of spinules. Anal operculum, furcal rami and furcal setae as in the female. Length of the long, strong seta (V): 0.253 $\mathrm{mm}$. Using a voucher of 13 male specimens, including the allo- 


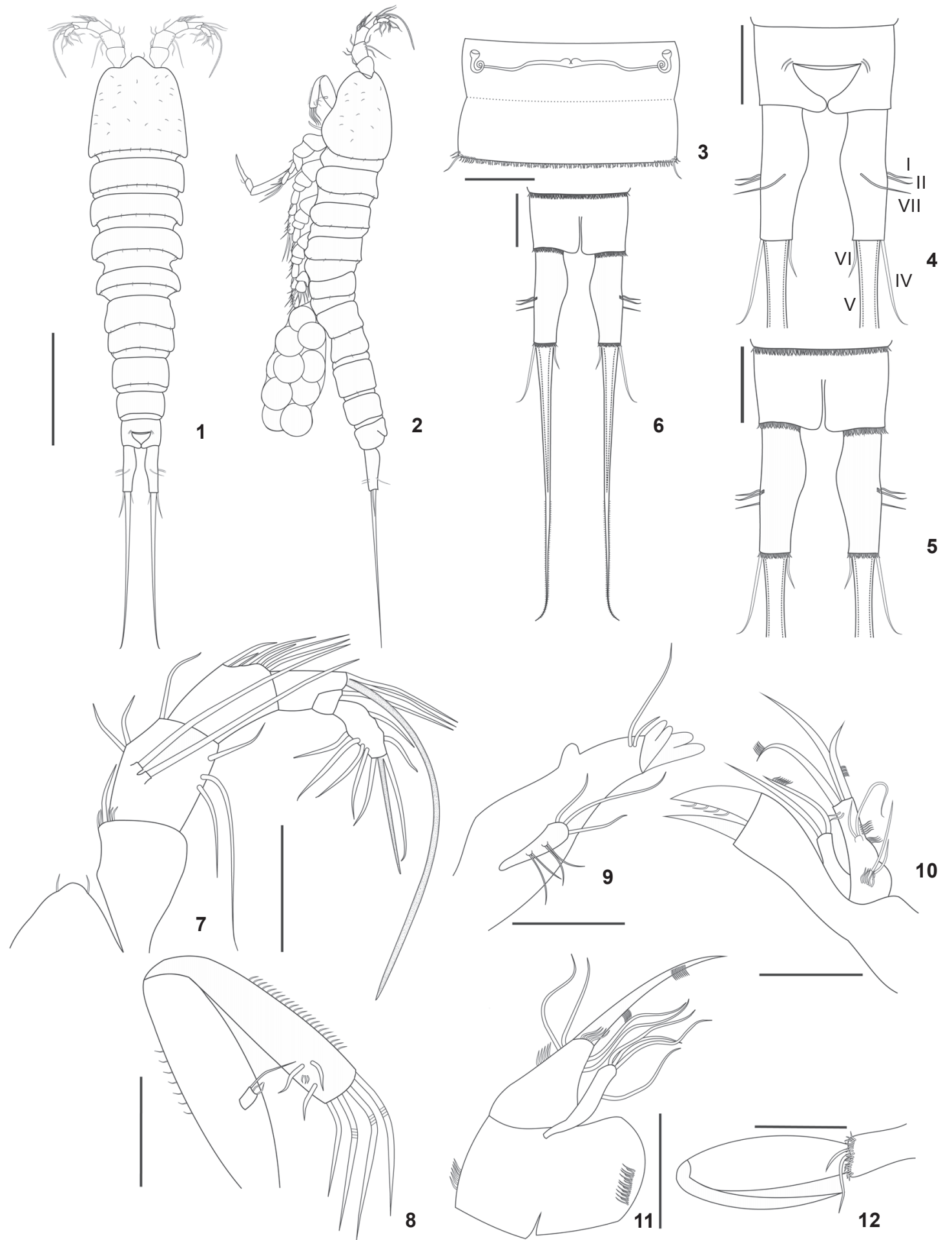

Figures 1-12. Quinquelaophonte aestuarii sp. nov., female holotype: (1) habitus, dorsal; (2) habitus, lateral; (3) genital field, ventral view; (4) furcal rami, dorsal view with anal operculum and furcal setae; (5) furcal rami, ventral view; (6) anal somite and furcal rami; (7) antennule and rostrum, ventral view; (8) antenna, anterior view; (9) mandible, anterior view; (10) maxillule, anterior view; (11) maxilla, anterior view; (12) maxilliped, anterior view. Scale bar: 1-2 =0.15 mm, 3-6 =0.05 mm, $7=0.015 \mathrm{~mm}, 9-12=0.025 \mathrm{~mm}$. 


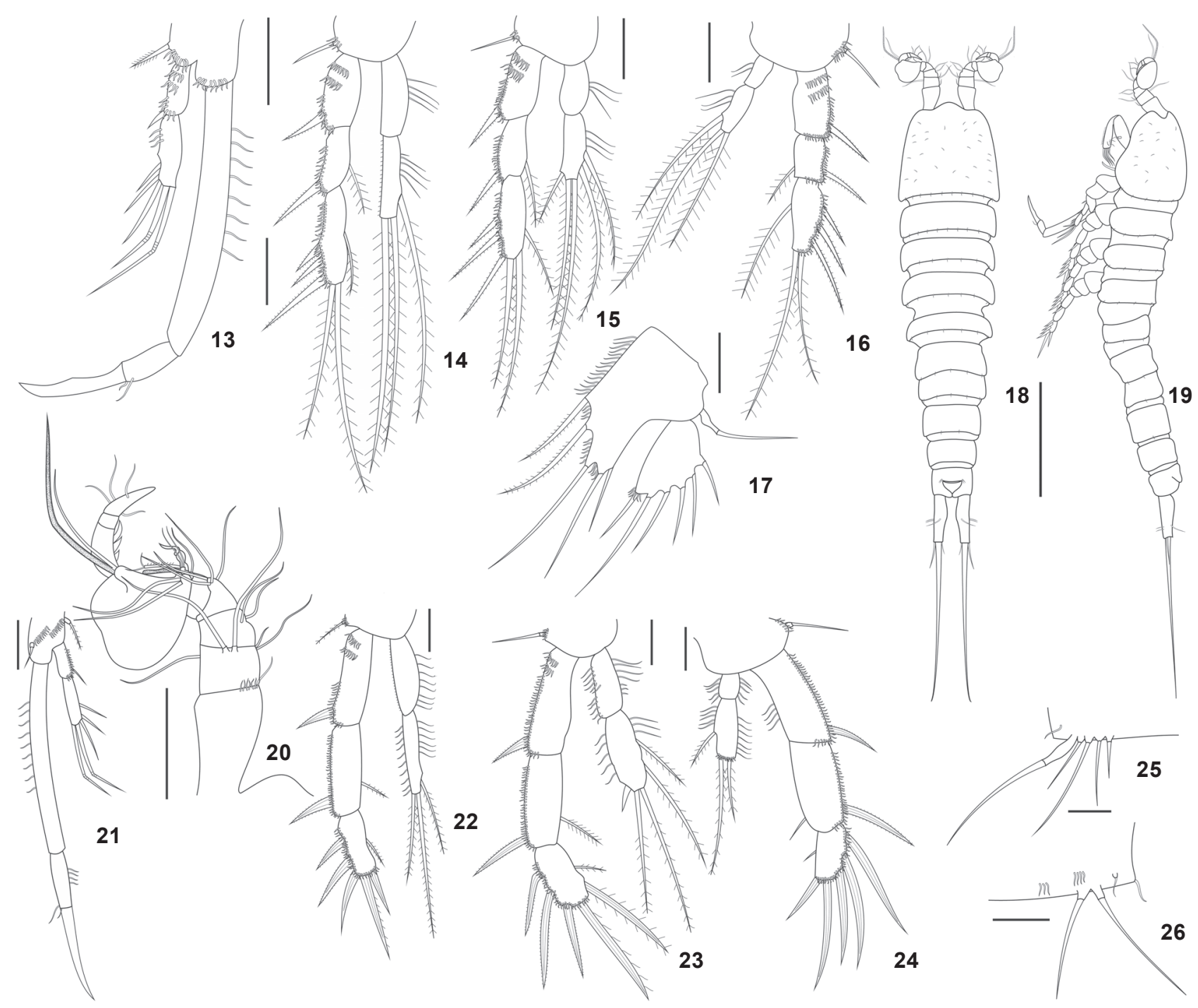

Figures 13-26. Quinquelaophonte aestuarii sp. nov. (13-17) female holotype: (13) P1, anterior view; (14) P2, anterior view; (15) P3, anterior view; (16) P4, anterior view; (17) P5, anterior view; (18-26) male allotype: (18) habitus, dorsal; (19) habitus, lateral; (20) antennule and rostrum, ventral view; (21) P1, anterior view; (22) P2, anterior view; (23) P3, anterior view; (24) P4, anterior view; (25) P5, anterior view; (26) P6, anterior view. Scale bars: 13-17, 20-26 $=0.025 \mathrm{~mm} ; 18-19=0.15 \mathrm{~mm}$.

type and other paratypes, the length of the terminal seta $(\mathrm{V})$ varied from $0.204 \mathrm{~mm}$ to $0.276 \mathrm{~mm}$ (mean $=0.233 \mathrm{~mm}$, standard deviation $=0.006$, median $=0.229 \mathrm{~mm}$ ). Antennule (Fig. 20): nine-segmented, subchirocer, with geniculation between sixth and seventh segment. Setal formula: 1(1),2(5),3(2),4(4), $5(1), 6(4+1$ pectiniform $+\mathrm{ae}+(1+\mathrm{ae})), 7(3), 8(0), 9(4)$. First segment with rows of distal spinules; sixth segment bearing one pectiniform seta and two aesthetascs, one of them fused basally to one seta; seventh segment bearing three strong spines on the inner margin. Antenna, mandible, maxillule, maxilla and maxilliped (not shown) as in the female. P1 (Fig. 21): basis with rows of spinules, a bipinnate outer spine and a smooth inner spine. Exopod and endopod as in the female. P2-P4 (Figs 22-24): Basis with rows of spinules and a plumose spine in P2 and a smooth seta in P3 and P4. Armature formula as in the female. P2 (Fig. 22): exopod larger and more strongly chitinised than in the female; first two segments relatively longer; outer and apical spines thicker. Second endopod segment with inner and apical setae shorter than in the female. P3 (Fig. 23): exopod larger and more strongly chitinised than in the female; first two segments relatively longer; outer and apical spines thicker; inner seta of third segment shorter. Outer seta of second endopod 
segment, reduced and modified to spine. P4 (Fig. 24): exopod larger and more strongly chitinised than in the female; first two segments relatively longer; outer and apical spines thicker; inner setae of second and third segments, shorter. Inner and apical setae of endopod, shorter than in the female. P5 (Fig. 25): reduced to four seta plus outer seta of basis. P6 (Fig. 26): represented by two setae of the same length.

The males are significantly longer than the females $(t=-2.36$, $\mathrm{p}=0.0135)$.

Examined material. All the studied specimens were collected by Michel Sciberras at the type locality: middle fringe of the midlittoral beach at Arroyo Pareja ( $\left.38^{\circ} 53^{\prime} \mathrm{S}, 62^{\circ} 07^{\prime} \mathrm{W}\right)$, Buenos Aires province, Argentina, from silt-clayey sediment covered with S. alterniflora. Holotype: adult female fixed in $4 \%$ formalin; appendages mounted on glycerol in eight slides (MACN-In 39586). Date of collection: February 21, 2013. Paratypes: two adult females fixed in $4 \%$ formalin saturated with Bengal Rose, mounted on glycerol, in five slides and six slides (MACN-In 39587) respectively. Date of collection: October 17, 2011. One adult male (allotype), fixed in $4 \%$ formalin, mounted on glycerol in seven slides (MACN-In 39588). Date of collection: February 21, 2013. Two male adults mounted on glycerol in seven slides each (MACN-In 39589). Date of collection: February 21, 2013.

Other revised material (not in the type series): Ten males and ten females from the same locality, in the collection of the Laboratorio de Zoología de Invertebrados I.

Etymology. The specific name aestuarii (genitive singular form of the Latin noun aestuarium) means "of the estuary".

\section{DISCUSSION}

Welis et al. (1982) questioned the status and position of $Q$. brevicornis and left it as incertae sedis near or perhaps within the genus Quinquelaophonte. This placement was based on the absence of males, which could have confirmed the sexually dimorphic generic diagnostic, and on the enigmatic presence of an inner seta on the first exopod segment of P4. However, the structure of the antennule, P5 and caudal rami in the female justify its inclusion in the genus Quinquelaophonte (Wells et al. 1982: 178).

All diagnostic characters of genus Quinquelaophonte are present in the new species: Female antennule with less than seven segments; caudal rami with a single well developed terminal seta; considerable modification of the male P2 to P4 exopods; broad female P5 baseoendopod, which reaches the end of the exopod; female P5 with angular, not rounded exopod; the unmodified male P2 endopod; and the male P5 reduced to four or five setae on a small protuberance of the segment edge (Wells et al. 1982).

The female of $Q$. aestuarii sp. nov. shares the armature formula of the last endopodal and last exopodal segment of P2, P3 and P4 with Q. varians only. The differences with females of the other species in Quinquelaophonte are listed on Table II. Quinquelaophonte aestuarii sp. nov. differs from $Q$.

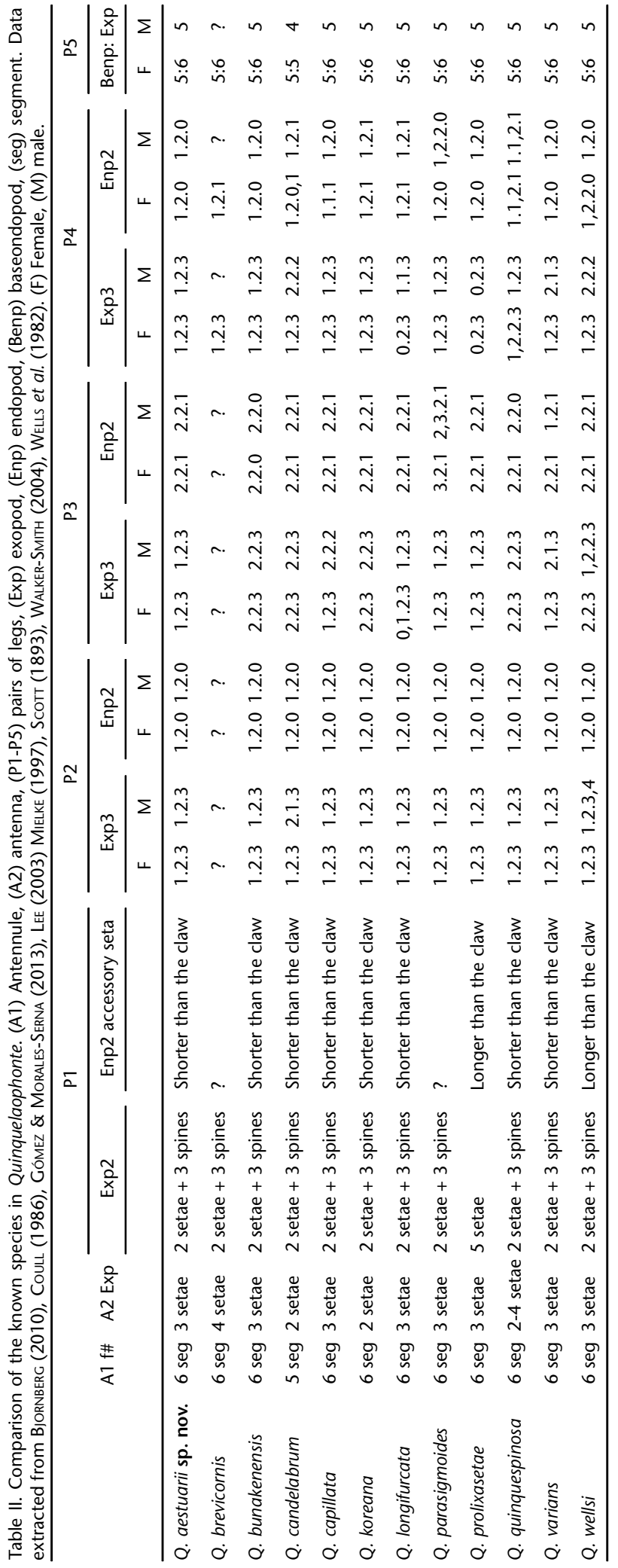


brevicornis in having no outer element in the second endopod segment of P4 (versus one outer element in the second endopod segment of $\mathrm{P} 4$ in Q. brevicornis); from Q. bunakenensis in having one inner element in the third exopod segment of P3 and one outer element in the second endopod segment of P3 (versus two inner elements in the third exopod segment of P3 and no outer element in the second endopod segment of P3 in $Q$. bunakenensis); from Q. candelabrum in having one outer element in the third exopod segment of P3 (versus two outer elements in the third exopod segment of P3 in Q. candelabrum); from Q. capillata in having two apical elements and no outer element in the second endopod segment of P4 (versus one apical element and one outer element in the second endopod segment of P4 in Q. capillata); from Q. koreana in having one inner element in the third exopod segment of P3 and no outer element in the second endopod segment of P4 (versus two inner elements in the third exopod segment of P3 and one outer element in the second endopod segment of P4 in Q. koreana); from $Q$. longifurcata in having one inner element in the third exopod segment of P4 and no outer element in the second endopod segment of P4 (versus no inner element in the third exopod segment of P4 and one outer element in the second endopod segment of P4 in Q. longifurcata); from Q. parasigmoides in having two inner elements in the second endopod segment of P3 (versus three inner elements in the second endopod segment of P3 in Q. parasigmoides); from Q. prolixasetae in having one inner element in the third exopod segment of P4 (versus no inner element in the third exopod segment of $\mathrm{P} 4$ in $Q$. prolixasetae); from Q. quinquespinosa in having one inner element in the third exopod segment of P3 and no outer element in the second endopod segment of P4 (versus two inner elements in the third exopod segment of P3 and one outer element in the second endopod segment of P4 in Q. quinquespinosa); from Q. wellsi in having one inner element in the third exopod segment of P3 (versus two inner elements in the third exopod segment of P3 in Q. wellsi).

Quinquelaophonte aestuarii sp. nov. differs from $Q$. varians in the A1 setal formula: 1(1),2(8),3(6),4(acrothek),5(1), $6(7+(1+\mathrm{ae}))$ in $Q$. aestuarii sp. nov. versus $1(1), 2(8), 3(6), 4(2+\mathrm{ae})$, 5(1),6(9-10+ae) in Q. varians; in having three geniculate setae in the A2 endopod (versus two geniculate setae in the A2 endopod in Q. varians); in having two bicuspidate teeth and two setae on the top margin in the mandible gnathobase (versus three digitiform teeth, three distally crenulated cylindrical teeth and a small lateral seta in the mandible gnathobase in $Q$. varians); in having two strong spines in the maxillule arthrite and three apical setae in the maxillule basis (versus five spines in the maxillule arthrite and four apical setae in the maxillule basis in Q. varians); in having one endite in the maxilla syncoxa (versus three endites in the maxilla syncoxa in Q. varians); in having rows of spinules in the maxillipeds basis (versus rows of short setules in the maxillipeds first endopod segment in $Q$. varians); in having one inner seta in the second exopod seg- ment of P2 and this is the shortest segment (versus no inner seta in the second exopod segment of P2 and this is the longest segment in Q. varians); in having two plumose setae in the P5 baseoendopod (versus no plumose seta in the P5 baseoendopod in Q. varians).

\section{ACKNOWLEDGMENTS}

We are very grateful to Agustin Menechella for his help with the preparation of drawings; to Julia Pizá and Marta Johansen, for English language editing; to Hugo Marrero, for his critical reading of the manuscript; and to Susana Johansen for helping with field work. M.S. is a fellow of CONICET (Consejo Nacional de Investigaciones Científicas y Técnicas); V.N.B. is a staff researcher of CONICET; N.J.C. is a staff researcher of CIC (Comisión de Investigaciones Científicas de la Provincia de Buenos Aires). This work was supported by grants from Universidad Nacional del Sur (Bahía Blanca, Argentina).

\section{LITERATURE CITED}

BJornberg, T. 2010. Quinquelaophonte varians n. sp. (Copepoda, Harpacticoida, Crustacea) and notes on its developmental stages. Pan-American Journal of Aquatic Sciences 62 (1): 62-77.

Coull, B.C. 1986. A new species of Pseudobradya and the rediscovery and correction of Quinquelaophonte capillata (Copepoda: Harpacticoida). Transactions of the American Microscopical Society 105 (2): 121-129. doi: 10.2307/3226384.

Dallwitz, M.J. 1993. Applications and Documentation of the DelTa System. Available online at: http://delta-intkey.com [Accessed: 02/IV/2014].

Gómez, S. \& F.N. Morales-Serna. 2013. On a small collection of Laophontidae T. Scott (Copepoda: Harpacticoida) from Mexico. II. New records of Quinquelaophonte Wells, Hicks and Coull and description of Onychoquinpes permixtionis gen. nov. et sp. nov. Journal of Natural History 47 (5-12): 381408. doi: 10.1080/00222933.2012.757658.

Higgins, R.P. \& H. Thiel. 1988. Introduction to the study of meiofauna. Washington, D.C., Smithsonian Institution, 488p.

LANG, K. 1948. Monographie der Harpacticiden. Lund, Hakan Ohlsson, 1683p.

LEE, W. 2003. A marine harpacticoid, Quinquelaophonte koreana sp. nov. From a Sandy beach in Korea (Crustacea: Copepoda). Zoological Science 20 (5): 657-668. doi: 10.2108/zsj.20.657.

MielKe, W. 1997. On a small collection of Laophontidae (Copepoda) from Sulawesi, Indonesia. Microfauna Marina 11: 223-250.

Pallares, R.E. 1966. Sobre una nueva especie de Porcellidium (Copepoda, Harpacticoida). Physis 26 (71): 113-120.

Pallares, R.E. 1968a. Copépodos marinos de la Ría Deseado (Santa Cruz, Argentina). Contribución sistemático-ecológico I. Servicio de Hidrografía Naval H-1024: 1-125. 
Pallares, R.E. 1968b. Copépodos marinos de la Ría Deseado (Santa Cruz, Argentina). Contribución sistemática-ecológica II. Physis 27 (75): 245-262.

Pallares, R.E. 1968c. Patagoniaella, nuevo género de la familia Ancorabolidae Sars, 1909 (Copepoda, Harpacticoida). Physis 27 (75): 461-469.

Pallares, R.E. 1969a. Catálogo preliminar de los copépodos harpacticoides marinos del Atlántico Sur y sector Atlántico del Antártico con bibliografía básica. Centro de Investigación de Biología Marina (CIBIMA) Contribución Científica 49: 1-64.

Pallares, R.E. 1969b. El género Scutellidium en la Ría Deseado (Crustacea, Copepoda). Physis 29 (78): 51-72.

Pallares, R.E. 1970. Copépodos marinos de la Ría Deseado (Santa Cruz, Argentina). Contribución sistemático-ecológica III. Physis 30 (80): 255-282.

Pallares, R.E. 1973a. El género Harpacticus en la Ría Deseado (Crustacea, Copepoda). Physis 32 (85): 275-288.

Pallares, R.E. 1973b. Sobre la presencia de Paramenophia platysoma en la Ría Deseado (Copepoda, Harpacticoida). Physis 32 (85): 289-293.

Pallares, R.E. 1975a. Copépodos marinos de la Ría Deseado (Santa Cruz, Argentina). Contribución sistemática-ecológica IV. Physis 34 (89): 213-227.

Pallares, R.E. 1975b. Sobre un nuevo género de la familia Laophontidae. Centro de Investigación de Biología Marina (CIBIMA) Contribución Científica 93: 1-25.

Pallares, R.E. 1975c. Copépodos harpacticoides marinos de Tierra del Fuego (Argentina). I. Isla de los Estados. Centro de Investigación de Biología Marina (CIBIMA) Contribución Científica 122: 1-34.

Pallares, R.E.1975d. Sobre el hallazgo de ejemplares masculinos de Paramenophia platysoma (Thompson and A. Scott, 1903) (Copepoda, Harpacticoida). Centro de Investigación de Biología Marina (CIMIBA) Contribución Científica 135: 1-6.

Pallares, R.E. 1977. Copépodos harpacticoides marinos de Tierra del Fuego (Argentina). II. Isla de los Estados. El género Diarthrodes Thompson, 1882. Centro de Investigación de Biología Marina (CIBIMA) Contribución Científica 141: $1-14$.

Pallares, R.E. 1979. Copépodos harpacticoides marinos de Tierra del Fuego (Argentina). III. Isla de los Estados. Centro de Investigación de Biología Marina (CIBIMA) Contribución Científica 142: 1-20.

Pallares, R.E. 1982. Copépodos harpacticoides marinos de Tierra del Fuego (Argentina). IV. Bahía Thetis. Centro de Investigación de Biología Marina (CIBIMA). Contribución Científica 186: 1-39.

Piccolo, M.C. \& G.M. Perillo. 1990. Physical characteristics of the Bahía Blanca estuary (Argentina). Estuarine, Coastal and Shelf Science 31: 303-317.

Ramírez, F.C. 1971. Paralteutha minuta, una nueva especie de copépodos (Harpacticoida, Peltidiidae), hallado en aguas costeras de Mar del Plata, Argentina. Revista del Museo de La Plata, Nueva Serie, Sección Zoología 11: 115-119.

ScotT, T. 1893. Report on Entomostraca from the Gulf of Guinea collected by John Rattray. Transactions of the Linnean Society of London, Zoology 6: 1-161.

Walker-Smith, G.K. 2004. A new species of Quinquelaophonte (Crustacea: Copepoda: Harpacticoida: Laophontidae) from Port Phillip Bay, Victoria, Australia. Memoirs of Museum Victoria 61 (2): 217-227.

Wells, J.B.J.; G.R.F. Hicks \& B.C. Coull. 1982. Common harpacticoid copepods from New Zealand harbours and estuaries. New Zealand Journal of Zoology 9 (2): 151-184. doi: 10.1080/03014223.1982.10423847.

Submitted: 02.IV.2014; Accepted: 16.IX.2014.

Editorial responsibility: Marcos D.S. Tavares 